\section{DIARY}

\section{AUGUST}

8th International Dental Ethics

and Law Congress

Date: 18-20 August 2010

Venue: University of Helsinki, Finland

www.ideals.ac

International Congress of Oral

Implantologists (ICOI) World Congress

Date: 26-28 August 2010

Venue: Convention Center

Hamburg/Germany

www.icoi-worldcongress-2010.com

\section{SEPTEMBER}

Training essentials: Employment law - rights and responsibilities

Date: 2 September 2010

Venue: BDA, London

Email: events@bda.org

www.bda.org/events

2010 FDI Annual World Dental Congress

Date: 2-5 September 2010

Venue: Centro de Convencões da Bahia,

Salvador da Bahia, Brazil

Email:congress@fdiworldental.org

www.fdiworldental.org

\section{BDA Northern Ireland Branch}

- Meet the BDA Chief Executive

Date: 7 September 2010

Venue: Medical Biology Centre,

Lisburn Road, Belfast

Email: events@bda.org

www.bda.org/events

BDA Scottish Scientific Conference 2010

Date: 10 September 2010

Venue: Doubletree by Hilton, Dunblane

Email: events@bda.org

www.bda.org/events

Aesthetic dentistry for the GDP (Belfast)

Date: 17 September 2010

Venue: Ramada, Belfast

Email: cappiah@rcseng.ac.uk

www.fgdp.org.uk

\section{Fall 2010 American Academy}

of Cosmetic Dentistry International

Meeting/British Academy of Cosmetic

Dentistry Annual Conference

Date: 23-25 September 2010

Venue: Hilton London Metropole Hotel,

London

Email: info@bacd.com

www.aacdlondon.com

\title{
HIGH STREET DENTISTS GRADUATE FROM NEW COURSE
}

The first cohort of students on a pioneering $\mathrm{MSc} / \mathrm{PG}$ Dip in Clinical Restorative Cosmetic Dentistry have graduated from the University of Central Lancashire (UCLan).

The course is aimed at providing clinicians with an understanding of managerial, clinical and research issues that will develop restorative and cosmetic dentistry within dental practice, and with the complementary skills required to contribute to and influence development and evaluation of dental practice. It is offered to high street dentists on a flexible, part time basis.

Graduate Dr Usman Ali of MJ Kenyon Dental Surgeons in Lytham said: 'After a few years in practice I noticed a lot of patients were starting to enquire about the cosmetic side of dentistry. It's an area that really interests me so when I saw the

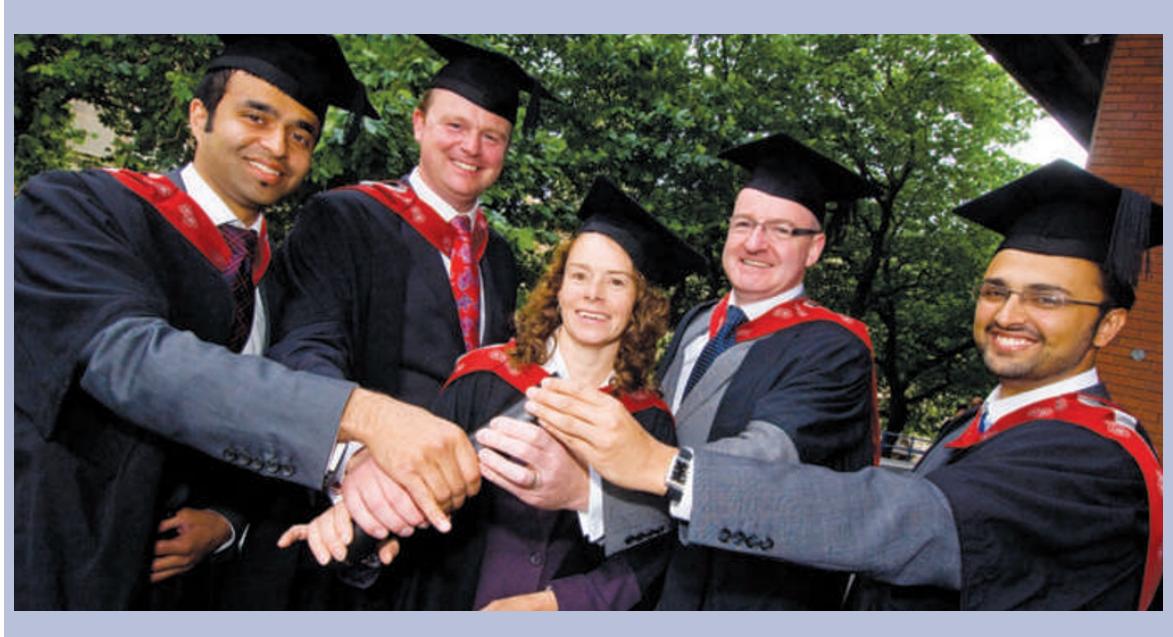

UCLan course advertised on my doorstep I thought I'd investigate further.'

Dr Ali was a little apprehensive about returning to study after ten years in practice but was impressed by the facilities at UCLan. 'I knew I'd made the right decision. Like myself, the other students on the course were all working in the profession and this helped us to support and learn from each other.'

'Our focus as an Institute is on continuing professional development, allowing general dental practitioners the opportunity to further their skills and education in their chosen area of interest, whilst maintaining their clinical practice,' said Professor StJohn Crean, Director of Dental Research and Knowledge Transfer and Head of UCLan's Institute of Postgraduate Dental Education.

\section{NEW WHITE PAPER SHORT ON DETAIL, SAYS BDA}

According to the BDA, the Government's latest White Paper Equity and excellence: liberating the NHS does not address dental services in detail or explain exactly what the implications of the new framework will be.

The White Paper sets out the Government's vision for the whole of the management of the NHS and future contracting and commissioning arrangements.

'It is promising to see that primary care dentistry will be commissioned by a new NHS Board,' said Chair of the General Dental Practice Committee (GDPC) Dr John Milne. 'Safeguarding dental services, whether provided by family practices or the salaried and specialist services, is paramount.

'It is reassuring that the Government has reiterated its pledge to pilot changes to the dental contract and we are urging the Minister to continue developing the pilots testing out the recommendations in the Steele report.'

Dr Milne was also pleased to see the emphasis on outcomes based on proven clinical indicators, rather than targets, and that quality will be incentivised.

The White Paper signals the start of an extensive consultation process that includes the publication of documents by the Department of Health. 